\title{
Untenable Dichotomies: De-gendering Political Economy
}

\author{
Elisabeth Prügl \\ Graduate Institute, Geneva
}

\begin{abstract}
:
Political Economy is inundated with foundational dichotomies, which constitute central concepts in its theorizing. Feminist scholarship has problematized the gender subtext of these dichotomies and the resulting blind spots, including the positioning of women's labour, processes of reproduction, and private households as marginal to the economy. The paper offers a reading of contemporary writings in Feminist Political Economy that is attuned to disrupting binaries. It interrogates first, how the opposition between production and reproduction is today put into question through the development of a care economy and through new theorizations of social reproduction. Second, I question the spatial opposition between the public and the private, the state and the household, an opposition that has long been a problem for those earning income in private spaces and that is increasingly made untenable by feminist literature that historicizes household governance. By destabilizing the gendered binaries of production/reproduction and public/private Feminist Political Economy brings into view blind spots in existing scholarship, including imbrications between logics of accumulation and public purpose, self-interest and care, and private household governance and the state, thereby opening up new thinking space for alternatives.
\end{abstract}

This is an Accepted Manuscript of an article published by Taylor \& Francis in Review of International Political Economy on October 20, 2020. Available online at https://doi.org/10.1080/09692290.2020.1830834 


\section{Untenable Dichotomies: De-gendering Political Economy}

Political Economy is inundated with foundational dichotomies, which constitute central concepts in its theorizing. They differentiate processes of production from reproduction, and of production from consumption. They distinguish values of exchange from use, and profit from care. They structure spaces, separating markets from the state, the economic and the social, factories from homes, and the public from the private. They oppose wage labour to subsistence, competition to reciprocity, and self-interest to altruism. Although accepted as common sense in the field, these dichotomies are thoroughly gendered, colouring the first part of the binary as masculine and the second as feminine, thereby establishing a hierarchy between them. Feminists have argued that such gendering is problematic because it propels gendered realities and a gendered organization of the economy.

Feminist Political Economy has long sought to counteract the devaluing of the feminine in these binaries. Starting from labour, feminist critiques of Political Economy have sought to valorise women's crucial but largely hidden and often unpaid work in homes, farms, and small businesses together with feminised and marginalised economic values thus produced. They also have analysed the violent appropriations of women's unpaid labour for purposes of social reproduction. In doing so, they have refused a positioning of women's labour and of private household spaces as the conceptual Other of Political Economy, 
outside privileged realms of production and accumulation. Feminist Political Economy has worked with the binaries it has inherited but is increasingly pushing beyond them.

Disrupting the gendered dichotomies of Political Economy is important for imagining alternatives that overcome inequalities and oppression based on gender and other intersecting status positions. As the editors of this special issue state in their introduction, scholarly blind spots have political and normative effects, influencing whose experiences are validated and whose agendas thrive (LeBaron et al., this issue). If scholarly knowledge thus carries performative force, gendered Political Economy participates in the perpetuation of gendered realities. Indeed, gendered dichotomies hold in place not only gender inequality, but prop up the panoply of existing hierarchies and hegemonies they encode. Gendered dichotomies also blind us to everyday economic practices that may exceed and contradict binary logics. J.K. Gibson-Graham has perhaps most forcefully sought to make visible diverse economies beyond the capitalist processes privileged in contemporary Political Economy, including non-market practices of care, cooperatives, community-supported agriculture, local and complementary currencies, and the social economy (Gibson-Graham, Cameron, and Healy 2013; Gibson-Graham 2008; see also Bedford in the NPE special issue). I align myself with these efforts, seeking to highlight in addition phenomena of economic governance hidden behind dichotomies. However, rather than attempting to change the story through bottom-up theorizing for the purpose of imagining alternative economies, I offer a reading of contemporary writings in Feminist Political Economy that is attuned to disrupting binaries. I 
seek to show how feminist theorizing negotiates inherited binaries and illustrate how seeming opposites inhabit each other, ultimately rendering the gendered dichotomies of Political Economy untenable.

Specifically, I explore two themes in contemporary Feminist Political Economy. The first focuses on the opposition between production and reproduction. Processes of social reproduction have received little attention in Political Economy research until feminists highlighted their centrality. Today the opposition between production and reproduction is put into question through the development of a care economy and through new feminist theorizations of social reproduction. Second, I focus on the spatial opposition between the public and the private, the state and the household. The economic and political roles of "private" households again have received little attention in Political Economy. However, the opposition has long been a problem for those earning income in private spaces and is increasingly made untenable by feminist literature that historicizes household governance.

The paper proceeds in two steps. First, I provide a review of the classical literature in Feminist Political Economy that introduced a focus on social reproduction and households in the 1970s and 1980s, highlighting the way in which this literature negotiates gendered binaries. Second, I enter the topic through the care economy and home-based work and show how Feminist Political Economy literature disrupts the gendered binaries of production/reproduction and public/private, thereby disturbing hierarchical arrangements, making visible hidden phenomena, and opening up thinking space 
for alternatives. I conclude by highlighting exemplary lines of inquiry into blind spots of Political Economy that are opened up once foundational dichotomies are problematized.

\section{Gendered Dichotomies in Political Economy}

Unlike orthodox economics, Marxism has given a name to women's reproductive labour and thus a language to Feminist Political Economy scholarship. It has shown the value of that which appears as Other in Marxism-women's unpaid work in households. The debates around "domestic labour" in the 1970s and 1980s were firmly anchored in the dualism of production and reproduction, and arguments over the relationships between "unproductive" domestic labour and "productive" (that is surplus-generating) labour outside the home were fierce (Molyneux 1979; Seccombe 1974).1 The debates were deeply political, informing movement activism in the Wages for Housework campaign, which argued that women's "reproductive" labour in the home was as important to capitalism as the typically male "productive" labour outside the home; the goal of the campaign was to valorise this labour. In the 1980s, a group of German feminist political economists further developed these ideas to encompass all unwaged labour-including those of peasants in subsistence agriculture, "the colonies," and "nature," introducing the notion of a "subsistence perspective" as an alternative to capitalist reasoning (Mies 2007; Mies, Bennholdt-Thomsen, and Werlhof 1988). Elaborations of the relationship between capitalism and subsistence work as "primitive accumulation" made visible the gendered

1 This is not the place to revisit these arguments. For retrospective appraisals see Toupin 2018 and Vogel 2000. 
violence of capitalist processes vis-à-vis subsistence producers. Like domestic labour, the subsistence perspective was an analytical construct but also anchored a political programme of opposition; its proponents argued that subsistence production should have priority over commodity production (Mies 1986; Federici 2004).

Heterodox feminist economists often negotiated similarly dualist logics, starting not from Marxism but from neoclassical economics. Some criticised the celebration of goals of efficiency and utility maximization in neoclassical economics and proposed a refocusing of economic theorizing from logics of rational choice to social provisioning and the achievement of human welfare, "from pecuniary pursuits and individual competition ... toward notions of sustenance, cooperation, and support" (Power 2004, 6; Nelson 1993). Others, following ideas of Amartya Sen, suggested that economic activity should be geared towards enhancing well-being and not just monetary gain, and that gender analysis is central to developing this new paradigm (Fukuda-Parr, Heintz, and Seguino 2013; Fukuda-Parr 2003). The gendered oppositions between provisioning and profit maximizing, well-being and monetary pursuits thus joined the oppositions of reproduction and production, home and work, subsistence and commodity production as heterodox feminists inserted themselves into economic theorizing. Political programs also followed from their suggestions, ranging from innovating ways of measuring women's household contribution and human development more broadly to institutionalizing gender analyses in economic policy-making (Himmelweit 2002). 
In highlighting gendered dualisms of production and reproduction, utility maximization and provisioning, feminist scholars attracted attention to traditional blind spots in Political Economy, and attributed value to women's labour, non-capitalist forms of production, and non-calculating reasoning. They also called out unrealistic, and indeed harmful, policy prescriptions blind to the second part of these dichotomies. Not enough of their insights have come to inform scholarship in Political Economy. Their continued marginalization was perhaps facilitated by framings of feminist ideas as Other, framings that were perhaps encouraged by feminist scholars themselves when they figured reproduction, subsistence, and provisioning as feminine, as signifying "the other economy" (Donath 2000, 116). Revisiting classical Political Economy gave them the instruments to make visible glaring blind spots, but these instruments also made it difficult to move beyond the gendered binaries that assigned the feminine to a secondary position.

\section{Disrupting Dichotomies}

Many economic practices are not easily contained into binary categories, and contemporary Feminist Political Economy drives towards their destabilization. In the following I hope to show this by examining the economics and politics of the care economy and of home-based work. The commercialisation of caring practices disturbs the production-reproduction dichotomy and invites new theorizing about the imbrications of economic rationality and caring. Conversely, home-based work problematizes the understanding of households as private and beyond the realms of public governance. 


\section{The care economy - beyond production and reproduction}

In the past 20 years, the idea of a serious investment into developing a "care economy" has emerged from feminist circles, pushed in the aftermath of the 2008 financial crisis, and again today, as a programme for economic recovery from the COVID-19 pandemic. Investing in social infrastructures, in particular in education, health and social services, would build a sustainable economy while securing jobs for a large number of workers. In contrast to the "green economy," the vision of a care economy has so far failed to gain significant traction in the public imaginary. However, it has inspired international policy-making, and the UN’s 2030 Agenda for Sustainable Development includes a target to "recognize and value unpaid care and domestic work" under its gender equality goal (International Labour Organization 2018, 24; UN Women 2019).

The empirical reality of an emerging care economy disrupts the oppositions between production and reproduction, paid and unpaid work, that continues to structure Political Economy and that inadvertently hides a range of phenomena that exceed the dichotomy. Under ILO definitions care work is not just work performed for love in households, but encompasses that which is performed for pay or profit ("care employment") together with that which is unpaid ("unpaid care work", "volunteer care work" or "unpaid trainee care work"). Although most care work globally is unpaid and is done by women, care employment is significant and rising. It today represents " 11.5 per cent of total global employment, or 19.3 per cent of global female employment" (International Labour Organization 2018, xxxvii). ILO simulations anticipate a rise in care employment by 74 per cent between 2015 and 2030, if current trends continue, 
and an increase of 130 per cent if the investments envisioned in the ILO's decent work agenda materialize (International Labour Organization 2018, xlii). There is thus today a sizeable and growing care industry, a significant employer of women, primarily in education, health and social work. Theorizing in Feminist Political Economy recognizes this kind of work and builds theory in which care labour exceeds its status as the Other of "productive" wage labour.

One recent effort is the reformulation of "social reproduction theory" (SRT). The concept is from Marx, who used it variably to address both the reproduction of capitalism as a system, but also the generational and everyday reproduction of labour power. Marxist feminists have called the first "societal reproduction," and the second "social reproduction," suggesting that Marx had very little to say about the second and seeking to further elaborate it (Luxton 2018; McGregor 2018; Mezzadri 2019). An often-cited definition goes back to Brenner and Laslett (1991, 314) who proposed that social reproduction means "the activities and attitudes, behaviors and emotions, and responsibilities and relationships directly involved in maintaining life on a daily basis and intergenerationally." Elias and Rai $(2019,203)$ shorten this succinctly to "all those activities involved in the production of life." In this formulation, reproduction is broadened significantly from the concept of domestic labour, no longer restricted to households, but encompassing in addition the (paid and unpaid) work in schools, hospitals and communities. Redefined as a form of production, it is no longer subsidiary to commodity production. Bhattacharya insists that the production of life (which, following Marx, she calls the production of labour power) does not take place in the "circuits of commodity production," thus retaining it as distinctive; yet she 
argues that production and reproduction are "separate and conjoined spaces" (Bhattacharya 2017, 7). SRT elaborates the relationship between production and reproduction as "necessary but contradictory:" opposing "the social labours involved in producing this and the next generation of workers" and "the capitalist drive to produce and accumulate surplus value" (Ferguson n.d.). The contradiction consists of the fact that "on the one hand, social reproduction is a condition of possibility for sustained capital accumulation; on the other, capitalism's orientation to unlimited accumulation tends to destabilize the very processes of social reproduction on which it relies" (Fraser 2016, 100). Fraser postulates that a "crisis of care" has emerged from this contradiction under contemporary conditions of financialised capitalism.

SRT has done much to provide a theoretical anchoring of practices of care, including paid care, moving such practices from their secondary status as "unproductive" to the centre of attention and making them a starting point for innovative theorising in Political Economy. It also has informed trenchant critiques of policy practices, making visible for example the pitfalls of one-sided efforts to move women into the labour force without assuring reproduction; or the violence of austerity policies that do not factor in the depletion of individuals, households, and communities that result (Rai, Hoskyns, and Thomas 2014); or the hazards of financializing reproduction through mortgage debt in the US (Roberts 2013). Social reproduction, the production of life, is no longer a marginal activity in these analyses but a process integral to, and indeed the starting point for theorizing in Political Economy. 
However, the realities of an emerging care economy also highlight the limits of the production-reproduction dichotomy by raising questions about the impacts of commodification and the character of motivations for work. First, care services today include an industry, and the production of life is increasingly integrated in circuits of commodity production. Accumulation may be limited in the care industry, because it cannot be made productive beyond a certain point (Horton 2019; Himmelweit 2002), and because it cannot be easily sliced into tasks amenable to discrete transactions (Hoppania and Vaittinen 2015). Yet, care has become a commodity sold in a market, has been financialised and organized along logics of efficiency. At the same time, this market is extensively structured by public purposes and supported by public funds. There is thus no prima facie reason to consider care a matter of either reproduction or production, of either producing life or a commodity.

Second, care employment is presumably motivated by the need to earn an income rather than altruism. Yet, it also invariably involves an emotional commitment that cannot be reduced to a rationalist logic of wage earning for survival. Although care workers are paid low wages and squeezed to the limit in the name of efficiency, they often establish close relationships with the people they care for that lead them to put the needs of others before self interest (Horton 2019). Care labour thus constitutes an anomaly - it is connected labour by definition, creating an interdependence between carers and those cared for, but it is also done for instrumental reasons of earning an income. ${ }^{2}$

\footnotetext{
2 For an overview of the rich sociological literature on emotional labor see Wharton 2009.
} 
The anomaly of an economic sector mixing logics of accumulation and the public good, and of labour motivated by both utility and altruism may disappear if we let go of gendered thinking that opposes production and reproduction, selfinterest and emotion. As Folbre and Nelson (2000) point out, real people take responsibilities towards themselves, their families, and others; and workers rarely are motivated only by money, instead deriving their identities from their work. Moreover, "real-world markets are often domains of rich and complex social relationships" functioning not only around calculated exchange, but also "including aspects of reward, appreciation, reparation, gift, and so on" (Folbre and Nelson 2000, 133). If this is so, perhaps accumulation tethered to public purposes, or care workers that earn an income are less of an oddity, and should receive more attention in theories of Political Economy. Letting go of gendered dichotomies brings into view political economies populated by embodied workers and vulnerable people, in which earning, profit and caring; production and reproduction; accumulation and public purpose are mutually imbricated. The political programme to develop a care economy needs to come to terms with these imbrications. And, if such an economy is to be less exploitative and oppressive, it needs theorizing that shows how caring-as a distinctive form of labour founded on human vulnerability and values of solidarity—can flourish as it is being commodified. 


\section{Home-based work and household rule - beyond public and private}

The historical development of industrial capitalism has entailed a highly gendered separation of home and workplace and with it the creation of a private space imagined as walled off from the polity and the market and governed by different rules (LeBaron 2010; Fraser 2016). Yet, the separation of home and work has never been complete. For peasants, domestic workers, industrial homeworkers, the self-employed, and now platform workers in the gig economy the home has always also been a workplace, shaped by the forces of markets and politics. According to ILO statistics, almost 70 per cent of workers in emerging and developing economies are classified as informal, i.e. they work in arrangements that are not covered by legal arrangements; ${ }^{3}$ women are disproportionately employed in this sector, in particular in low-income activities (Mezzadri 2019, 37; Haspels and Matsuura 2015, 4-5). They work as small traders, casual labourers, assembly workers, sex workers and maids, often in homes or using homes as a base. Today, an extensive body of feminist literature documents this labour, counteracting its obfuscations in Political Economy, the understanding that it is marginal and on a trajectory of elimination. It details low incomes, miniscule wages, an absence of social protection, and struggles for recognition (Fish 2017). It unveils constructions of home-based work as not real work, a leisure activity, something that is supplemental, a diversion for women who do not otherwise do anything of value (Prügl 1999; Mies 2012). It also illustrates double tasking and the inevitable interweaving of paid and unpaid work in households.

\footnotetext{
${ }^{3}$ Labour statistics do not distinguish by the location of work, but the informal economy provides an approximation for work based in homes.
} 
Home-based workers belie the image of the home as a private space dedicated to biological and social reproduction and beyond the reach of the state. For, even if their labour tends to be outside formal regulation, it is regulated informally through gender norms and administrative practices. As income-pooling and sometimes labour-pooling units (Smith and Wallerstein 1992, 7) household are sites of governance, in which women, men, and children assume different roles and associated status positions (Folbre 1986). Households may be transnational, as in the case of migrants, but they invariably link people through "ties of economic and emotional interdependence and structures of decision making or governance" (Safri and Graham 2010, 107 emphasis added). Gendered norms of kinship prop up these structures, including gender divisions of labour that constitute the conditions of possibility for exploitative home-based work. Such gendered norms are reinforced through administrative practices that affirm the primacy of work outside the home, and the gender division of labour. For example statistical rules that construct a "production boundary" between unpaid subsistence labour and unpaid care labour (typically female), function to exclude the latter from national accounts and thereby deny its value (DeRock 2019). ${ }^{4}$

\footnotetext{
4 The UN System of National Accounts (SNA) recognizes that production may encompass not only paid, but also unpaid work. It includes in its calculations work that produces "household goods for consumption, such as food from a garden, firewood or water," but excludes from such calculations unpaid care and domestic work (UN Women 2019, 143). Unpaid care labour in peasant households is likely to be extensive as care dependency ratios are almost three times as high for low-income countries than they are for high-income countries (International Labour Organization 2018, 23).
} 
Household governance thus is not contained within the privacy of homes, but characterizes societies more broadly. Patricia Owens traces historically how household rule has shaped the meaning of society, including since the $19^{\text {th }}$ century the management of the social realm, in the form of a "modern public household ... in which the life processes of its members were reproduced and ordered" (Owens 2015, 124). Seeking to historicize the invention of society, she sees its roots in household rule (oikonomia), the realm of necessity and violence that was counter-posed to the freedom of the polis in Greek philosophy. Yet, she rejects liberal theorisations of the state as built on the polis and thus as the antithesis of the household. Instead, she conceives of the nation-state as "a distinctively modern and bureaucratic social form of household rule" (Owens $2015,6)$. Such household rule has always been gendered. Indeed, gender norms are deeply imbricated in societies and social policy, an aspect of the biopolitical state administering its population.

The fact that neoliberal welfare state restructuring is affecting household structures is evidence of this historically-developed connection (LeBaron 2010), as is the fact that households have morphed in conjunction with regimes of accumulation. In the West, these changes have included the "housewifization" of women under competitive capitalism in the $19^{\text {th }}$ century, the creation of the household as a site of consumption together with the establishment of the male breadwinner ideal under Fordism, and the creation of the two-earner household under contemporary financialized capitalism (Fraser 2016). Conversely, patriarchal household rule makes a public appearance in rules that prop up capitalism through a variety of gender regimes (Wöhl 2014; Bruff and Wöhl 
2016), in punitive processes of primitive accumulation that sustain gender divisions of labour (Roberts 2017), and in crisis politics (Kantola and Lombardo 2017; Hozic and True 2016).

I have arrived at an odd place with "private" households emerging as sites of ruthlessly exploitative labour and the "public" state as the site of household rule, "caring" for its population. The figure of the home-based worker led me there as she disobeys the separation of public and private spheres in Political Economy. She makes visible the home as a site of exploitation and value production, brings into view households as both deeply gendered and historically variable, and highlights the way in which state policies draw on patriarchal household rule when inventing varieties of gender regimes. But she also instructs us that households are at the core of politics and economics, and invites us to theorize householding beyond frozen dichotomies of public and private. Propositions for "commoning" as an alternative to capitalist practices resonate with this, i.e. for relational practices that establish "rules or protocols for access and use, taking care of and accepting responsibility for a resource, and distributing the benefits in ways that take into account the wellbeing of others" (Gibson-Graham, Cameron, and Healy 2016). If this sounds like household pooling made public, then this is perhaps precisely because proponents of commoning also treat reproduction as a commons, a public good. Moreover, they recognise that such householding is not only an economic but also a political practice that invariably entails the formation of (more or less unequal) communities. Disrupting the public/private distinction from the diverse perspectives of home-based workers in this way opens up interesting thinking space about forming less hierarchical 
and more solidarity economic communities, including those not geographically bounded.

\section{Conclusion}

My purpose in this paper has been to show how Feminist Political Economy disturbs taken for granted dichotomies, in particular the oppositions between production and reproduction, self-interest and caring, work and home, public and private, rendering them untenable in the face of emerging practices and impracticable for imagining alternative futures. The figure of the paid care worker outside the home destabilizes gendered dichotomies as she signifies both accumulation and public purpose, self-interest and altruism. The figure of the home-based worker moreover disrupts the association of home with privacy and the framing of the polity and economy as public. When these liminal figures move to the centre of Political Economy, self-interested wage labour and altruistic caring, profit and public purpose no longer constitute opposites, but materialize as mutually imbricated. Similarly, households and societies emerge as both public and private, as sites of both solidarity and rule.

Why is this important? As I am revising this paper, the COVID-19 pandemic is in full bloom, painfully surfacing the weakness of streamlined health systems operating on cheapened and feminized labour, the absence of social security for way too many, the double and triple burdens of parents working, teaching and caring at home, and the salience of domestic violence in these settings. In other words, it brings to light financialialised capitalism's parasitic dependence on social reproduction and feminized care labour on the one hand, and on 
patriarchal household governance on the other. At the same time, the pandemic has spawned remarkable acts of human solidarity and caring, which cannot be thought of as ancillary to or outside of the economy.

We need more scholarship that recognizes the complexity of embodied lives under contemporary capitalism, lives that cannot be sorted into feminine and masculine experiences and categories, but are lived and structured in the intersections of gender, race, class, sexuality, geography, and citizenship status. Starting from the liminal figures of the home-based worker and the paid care worker intersectional feminist insights seed a profound shift in understanding Political Economy, bringing into view the lived realities of a majority. Political Economists that move those at the margins to the centre, might shed light on how embodied meaning-making and interdependence operate in profit ventures beyond abstract logics of self-interest; how human vulnerability and the need for care constitute an internal limit to processes of accumulation (in care facilities and beyond); and how interdependences of caring can spawn oppositional practices in the midst of exploitation. They also might address how intersectionally gendered spaces of solidarity—the family as much as the welfare state-breed exploitation and oppression; and how new forms of householding beyond the boundaries of production and reproduction, public and private can grow new economies and communities. Feminist political economists working on these topics are founding a new Political Economy that diffracts gendered dichotomies in order to enable more complicated, and I would argue, more practical understandings for seeding alternative futures. 


\section{Works Cited}

Bhattacharya, Tithi. 2017. 'Introduction: Mapping Social Reproduction Theory'. In Social Reproduction Theory: Remapping Class, Recentering Oppression, edited by Tithi Bhattacharya, 1-20. London: Pluto Press.

Brenner, Johanna, and Barbara Laslett. 1991. 'Gender, Social Reproduction, and Women's Self-Organization: Considering the U.S. Welfare State'. Gender \& Society 5 (3): 311-33. https://doi.org/10.1177/089124391005003004.

Bruff, Ian, and Stefanie Wöhl. 2016. 'Constitutionalizing Austerity, Disciplining the Household: Masculine Norms of Competitiveness and the Crisis of Social Reproduction in the Eurozone'. In Scandalous Economics: Gender and the Politics of Financial Crises, edited by Aida Hozic and Jacqui True, 92-108. New York: Oxford University Press.

Callon, Michel. 1998. 'Introduction: The Embeddedness of Economic Markets in Economics'. The Sociological Review 46 (1_suppl): 1-57. https://doi.org/10.1111/j.1467-954X.1998.tb03468.x.

DeRock, Daniel. 2019. 'Hidden in Plain Sight: Unpaid Household Services and the Politics of GDP Measurement'. New Political Economy, October, 1-16. https://doi.org/10.1080/13563467.2019.1680964.

Donath, Susan. 2000. 'The Other Economy: A Suggestion for a Distinctively Feminist Economics'. Feminist Economics 6 (1): 115-23. https://doi.org/10.1080/135457000337723.

Elias, Juanita, and Shirin M. Rai. 2019. 'Feminist Everyday Political Economy: Space, Time, and Violence'. Review of International Studies 45 (2): 201-20. https://doi.org/10.1017/S0260210518000323.

Federici, Silvia. 2004. Caliban and the Witch. New York; London: Autonomedia ; Pluto, distributor].

Ferguson, Susan. n.d. 'Social Reproduction Theory: What's the Big Idea?' Accessed 3 June 2019. https://www.plutobooks.com/blog/socialreproduction-theory-ferguson/.

Fish, Jennifer N. 2017. Domestic Workers of the World Unite!: A Global Movement for Dignity and Human Rights. NYU Press. https://muse.jhu.edu/book/56537.

Folbre, Nancy. 1986. 'Cleaning House: New Perspectives on Households and Economic Development'. Journal of Development Economics 22 (1): 5-40.

Folbre, Nancy, and Julie A Nelson. 2000. 'For Love or Money-Or Both?' Journal of Economic Perspectives 14 (4): 123-40. https://doi.org/10.1257/jep.14.4.123.

Fraser, Nancy. 2016. 'Contradictions of Capital and Care'. New Left Review, no. 100 (August): 99-117.

Fukuda-Parr, Sakiko. 2003. 'The Human Development Paradigm: Operationalizing Sen's Ideas on Capabilities'. Feminist Economics 9 (2-3): 301-17. https://doi.org/10.1080/1354570022000077980.

Fukuda-Parr, Sakiko, James Heintz, and Stephanie Seguino. 2013. 'Critical Perspectives on Financial and Economic Crises: Heterodox Macroeconomics Meets Feminist Economics'. Feminist Economics 19 (3): 4-31. https://doi.org/10.1080/13545701.2013.806990. 
Gibson-Graham, J. K., Jenny Cameron, and Stephen Healy. 2013. Take Back the Economy: An Ethical Guide for Transforming Our Communities. U of Minnesota Press.

Gibson-Graham, J.K. 2008. 'Diverse Economies: Performative Practices for `other Worlds”. Progress in Human Geography 32 (5): 613-32. https://doi.org/10.1177/0309132508090821.

Gibson-Graham, J.K., Jenny Cameron, and Stephen Healy. 2016. 'Commoning as Postcapitalist Politics'. In Releasing the Commons: Rethinking the Futures of the Commons, edited by Ash Amin and Philip Howell, 1st ed. Abingdon, Oxon; New York, NY : Routledge, 2016. | Series: Routledge studies in human geography: Routledge. https://doi.org/10.4324/9781315673172.

Haspels, Nelien, and Aya Matsuura. 2015. 'Home-Based Workers: Decent Work and Social Protection through Organization and Empowerment:

Experiences, Good Practices and Lessons from Home-Based Workers and Their Organizations'. Jakarta: International Labour Office. https://www.ilo.org/wcmsp5/groups/public/---asia/---ro-bangkok/--ilo-jakarta/documents/publication/wcms_436853.pdf.

Himmelweit, Susan. 2002. 'Making Visible the Hidden Economy: The Case for Gender-Impact Analysis of Economic Policy'. Feminist Economics 8 (1): 49-70. https://doi.org/10.1080/13545700110104864.

Hoppania, Hanna-Kaisa, and Tiina Vaittinen. 2015. 'A Household Full of Bodies: Neoliberalism, Care and "the Political"'. Global Society 29 (1): 70-88. https://doi.org/10.1080/13600826.2014.974515.

Horton, Amy. 2019. 'Financialization and Non-Disposable Women: Real Estate, Debt and Labour in UK Care Homes': Environment and Planning A: Economy and Space, July. https://doi.org/10.1177/0308518X19862580.

Hozic, Aida, and Jacqui True, eds. 2016. Scandalous Economics: Gender and the Politics of Financial Crises. Oxford: Oxford University Press. https://global.oup.com/academic/product/scandalous-economics9780190204235.

International Labour Organization. 2018. Care Work and Care Jobs for the Future of Decent Work. Geneva: International Labour Office.

Kantola, Johanna, and Emanuela Lombardo. 2017. Gender and the Economic Crisis in Europe: Politics, Institutions and Intersectionality. Springer.

LeBaron, Genevieve. 2010. 'The Political Economy of the Household: Neoliberal Restructuring, Enclosures, and Daily Life'. Review of International Political Economy 17 (5): 889-912. https://doi.org/10.1080/09692290903573914.

Luxton, Meg. 2018. 'The Production of Life Itself: Gender, Social Reproduction and IPE'. In Handbook of the International Political Economy of Gender, edited by Juanita Elias and Adrienne Roberts, 23-36. Cheltenham, UK; Northampton, MA: Edward Elgar Publishing.

McGregor, Sheila. 2018. 'Social Reproduction Theory: Back to (Which) Marx? International Socialism'. International Socialism: A Quarterly Review of Socialist Theory, no. 160 (October). http://isj.org.uk/social-reproductiontheory/.

Mezzadri, Alessandra. 2019. 'On the Value of Social Reproduction'. Radical Philosophy 2 (4): 9. 
Mies, Maria. 1986. Patriarchy and Accumulation on a World Scale: Women in the International Division of Labour. London: Zed Books.

-_- 2007. 'Patriarchy and Accumulation on a World Scale Revisited.(Keynote Lecture at the Green Economics Institute, Reading, 29 October 2005)'. International Journal of Green Economics 1 (3-4): 268-275.

- - - 2012. The Lace Makers of Narsapur. Spinifex Press.

Mies, Maria, Veronika Bennholdt-Thomsen, and Claudia von Werlhof. 1988. Women: The Last Colony. Zed Books.

Molyneux, Maxine. 1979. 'Beyond the Domestic Labour Debate'. New Left Review 116 (3): 27.

Nelson, Julie A. 1993. 'The Study of Choice or the Study of Social Provisioning? Gender and the Definition of Economics'. In Beyond Economic Man, edited by Marianne A. Ferber and Julie A. Nelson, 23-36. Chicago: University of Chicago Press.

Owens, Patricia. 2015. Economy of Force: Counterinsurgency and the Historical Rise of the Social. Cambridge, England: Cambridge University Press.

Power, Marilyn. 2004. 'Social Provisioning as a Starting Point for Feminist Economics'. Feminist Economics 10 (3): 3-19. https://doi.org/10.1080/1354570042000267608.

Prügl, Elisabeth. 1999. The Global Construction of Gender: Home-Based Work in the Political Economy of the 20th Century. Columbia University Press.

Rai, Shirin M., Catherine Hoskyns, and Dania Thomas. 2014. 'Depletion: The Cost of Social Reproduction'. International Feminist Journal of Politics 16 (1): 86-105. https://doi.org/10.1080/14616742.2013.789641.

Roberts, Adrienne. 2013. 'Financing Social Reproduction: The Gendered Relations of Debt and Mortgage Finance in Twenty-First-Century America'. New Political Economy 18 (1): 21-42. https://doi.org/10.1080/13563467.2012.662951.

-_- 2017. Gendered States of Punishment and Welfare: Feminist Political Economy, Primitive Accumulation and the Law. Abingdon and New York: Routledge.

Safri, Maliha, and Julie Graham. 2010. 'The Global Household: Toward a Feminist Postcapitalist International Political Economy'. Signs: Journal of Women in Culture and Society 36 (1): 99-125. https://doi.org/10.1086/652913.

Seccombe, Wally. 1974. 'The Housewife and Her Labour under Capitalism'. New Left Review 83: 3-24.

Smith, Joan, and Immanuel Wallerstein. 1992. Creating and Transforming Households: The Constraints of the World-Economy. Cambridge University Press.

Toupin, Louise. 2018. Wages for Housework: A History of an International Feminist Movement, 1972-77. UBC Press.

UN Women. 2019. Progress of the World's Women 2019-2020: Families in a Changing World. New York: UN Women.

Vogel, Lise. 2000. 'Domestic Labor Revisited'. Science \& Society 64 (2): 151-79.

Wharton, Amy S. 2009. 'The Sociology of Emotional Labor'. Annual Review of Sociology 35 (1): 147-65. https://doi.org/10.1146/annurev-soc-070308115944. 
Wöhl, Stefanie. 2014. 'The State and Gender Relations in International Political Economy: A State-Theoretical Approach to Varieties of Capitalism in Crisis'. Capital \& Class 38 (1): 87-99. 